\title{
IDEOLOGICZNE OBLICZE ODBUDOWY ŚRÓDMIEŚCIA WARSZAWY ZE ZNISZCZEŃ PO II WOJNIE ŚWIATOWEJ
}

\begin{abstract}
Streszczenie. Celem artykułu jest udowodnienie tezy głoszącej, że odbudowa Warszawy ze zniszczeń II wojny światowej była w rzeczywistości budową nowej stolicy państwa socjalistycznego zgodnie z marksistowskimi regułami zagospodarowania przestrzennego. Przebudowie Śródmieścia Warszawy władze komunistyczne przypisywały szczególne znaczenie. Przedwojenna zabudowa dzielnicy była traktowana jako symbol kapitalistycznych stosunków społecznych, w których uprzywilejowane miejsce zajmowała mieszczańska klasa średnia.
\end{abstract}

Punktem wyjścia rozważań jest omówienie kwestii mijającego się z prawdą historyczną przedstawiania przez Polską Partię Robotniczą, a następnie Polską Zjednoczoną Partię Robotniczą stopnia i przyczyn zniszczeń stolicy, powstałych podczas II wojny światowej. W propagandzie nowej władzy główny akcent został położony na niszczycielską działalność okupanta hitlerowskiego, pomijany - bądź przedstawiany w fałszywym świetle - był okres sowieckich nalotów oraz szkody, jakie powstały podczas wyzwalania stolicy.

W drugiej części artykułu omówiono ideologiczne podstawy odbudowy Śródmieścia. Zgodnie z założeniami komunistów odbudowie stolicy przyświecała idea miasta jako układu stosunkowo zwięzłego i zorganizowanego w formie kompozycji architektonicznych powiązanych $w$ jedną całość. Miasto powinno mieć centrum o charakterze społeczno-politycznym, a place i ulice były traktowane jako tereny życia zbiorowego. Zniesiony miał zostać podział na lepsze i gorsze dzielnice.

W ostatniej części artykułu autorka starała się odpowiedzieć na pytane o zakres autonomii architektów i urbanistów z Biura Odbudowy Stolicy, na ile ich plany i koncepcje były uwarunkowane wytycznymi partyjnych funkcjonariuszy.

Słowa kluczowe: stolica, ideologia, odbudowa, Śródmieście Warszawy, Biuro Odbudowy Stolicy, architektura, historia Warszawy, urbanistyka 
Powojenna Warszawa, wznoszona na zgliszczach przedwojennej, z założenia nie mogła być tym samym miastem, co przed 1939 r. Państwo socjalistyczne zaplanowało budowę nowej stolicy zgodnie z marksistowskimi regułami zagospodarowania przestrzennego. Względy ideologiczne leżały u podstaw zarówno wyburzania zachowanych budowli, jak i tworzenia nowych.

Celem artykułu jest przedstawienie charakteru i etapów budownictwa socjalistycznego, kształtującego nową Warszawę, zarówno co do ich treści, jak i wyrazu architektonicznego. Autorka stawia pytanie o wpływ tej architektury na powstanie nowej „psychiki zbiorowej” społeczeństwa socjalistycznego.

Artykuł składa się z trzech części. Pierwsza ma na celu przedstawienie, zgodnie z obecną wiedzą historyczną, przyczyn i zakresu zniszczeń stolicy podczas II wojny światowej. Część druga opisuje założenia ideologiczne, na których realizowano odbudowę stolicy. Część trzecia dotyczy wpływu rządzących na prace architektoniczne i urbanistyczne, prowadzone przez Biuro Odbudowy Stolicy (BOS).

Narracja historyczna tego artykułu jest poprowadzona przez autorkę od wybuchu II wojny światowej do roku 1950, w którym nastąpiło rozwiązanie BOS. Zakres terytorialny badań stanowi obszar Śródmieścia Warszawy w obrębie granic z 1939 r., czyli teren ograniczony umownie od wschodu Wisłą, od południa ulicą Rakowiecką, od zachodu Towarową i Okopową, a od północy torami linii obwodowej. W jego skład oprócz ścisłego centrum wchodziły zatem również Muranów i Powiśle oraz część Woli.

\section{Fazy niszczenia zabudowy i infrastruktury Śródmieścia Warszawy podczas II wojny światowej i po niej}

W procesie niszczenia zabudowy i infrastruktury Śródmieścia można wyróżnić trzy główne fazy: pierwsza przypada na okres II wojny światowej, druga faza to czas działań saperskich bezpośrednio po wyzwoleniu stolicy, trzecia faza, którą można określić mianem celowego wyburzania dawnej zabudowy w imię stworzenia nowej stolicy, trwała aż do końca lat sześćdziesiątych XX w., kiedy to z mapy Śródmieścia bezpowrotnie zniknęły obiekty o dużej wartości historycznej (Ryc. 1). 
WARSZAWA 1945 R. STAN ZABUDOWY PO ZAKOŃCZENIU WOJNY: ZACHOWANEJ

I ZNISZCZONEJ

WARSAW, 1945 - AT WAR'S END - PRESERVED AND DESTROYED BUILDINGS

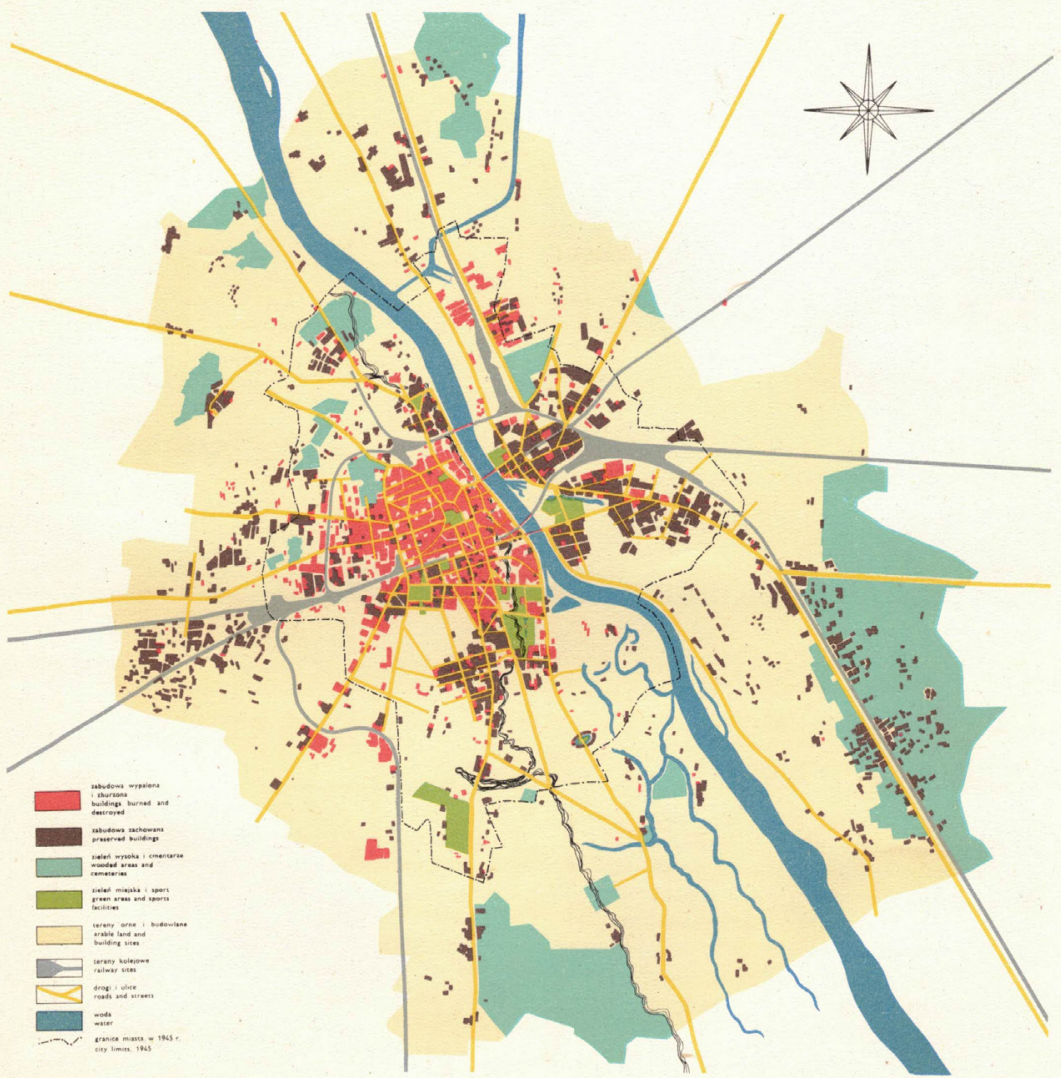

Ryc. 1. Stan zachowanej i zniszczonej zabudowy Warszawy w $1945 \mathrm{r}$.

(źródło: A. Cıвorowskı, Warszawa. O zniszczeniu i odbudowie miasta, Warszawa 1964, s. 65) 
Szacuje się, że w wyniku nalotów bombowych Luftwaffe w 1939 r. zniszczeniu uległo około 10-12\% zabudowy miasta. Najbardziej ucierpiał rejon Śródmieścia, spłonął wówczas Zamek Królewski, a także Dworzec Główny oraz wiele budynków mieszkalnych i użyteczności publicznej’. Po zdobyciu stolicy przez wojska niemieckie naczelnym architektem miasta Warszawy został mianowany ówczesny kierownik Urzędu Budownictwa Rzeszy, Friedrich Pabst. Pod jego kierownictwem w roku 1940 architekci z pracowni urbanistycznej Würzburga na polecenie generalnego gubernatora Hansa Franka stworzyli plan przebudowy Warszawy w miasto prowincjonalne o charakterze tranzytowym. Dawna stolica Polski miała nosić nazwę „Nowe niemieckie miasto Warszawa”. Postanowiono zachować Stare Miasto jako rdzennie niemieckie, a pozostałości wypalonego podczas bombardowań Zamku Królewskiego przeznaczono do wyburzenia, podobnie jak znaczną część zabudowy śródmiejskiej, gdzie miały powstać osiedla mieszkalne dla niemieckich osadników ${ }^{2}$.

Kolejne zniszczenia zabudowy przyniosły cykliczne naloty radzieckie, rozpoczęte w czerwcu $1941 \mathrm{r}^{3}$ Podczas pierwszego z nich, wieczorem 23 czerwca 1941 r., celami były głównie mosty na Wiśle oraz obiekty zaanektowane przez Niemców. Mosty przetrwały atak, który spowodował jednak spore zniszczenia, głównie na terenach Śródmieścia. Ponownie zbombardowano - uszkodzony już w 1939 r. - Teatr Wielki oraz liczne kamienice, m.in. przy ulicy Focha i Krakowskim Przedmieściút.

Znacznie większe zniszczenia przyniosły akcje lotnictwa ZSRR latem $1942 \mathrm{r}$. oraz w maju 1943 r. Tragiczny w skutkach był nalot w nocy z 20 na 21 sierpnia 1942 r., bomby trafiły w ponad sto budynków, wzniecając liczne pożary5. Dla Śródmieścia najtragiczniejszy był nalot w nocy z 1 na 2 września 1942 r. W jego wyniku około stu budynków zostało wypalonych lub poważnie uszkodzonych. Rejon bombardowania objął m.in. Getto Warszawskie i Cmentarz Powązkowski oraz jedno z największych targowisk okupowanej stolicy - Kercelak ${ }^{6}$.

\footnotetext{
1 A. Ciborowski, Warszawa. O zniszczeniu i odbudowie miasta, Warszawa 1964, s. 44.

2 M.M. Drozdowski, A. Zahorski, Historia Warszawy, Warszawa 2004, s. 322.

3 G. Piątek, Najlepsze miasto świata. Warszawa w odbudowie 1944-1949, Warszawa 2020,

${ }^{4}$ K. Dunin-WĄsowicz, Warszawa w latach 1939-1945, Warszawa 1984, s. 121.

5 W. Bartoszewski, 1859 dni Warszawy, Kraków 2008, s. 370-371.

6 T. Szarota, Okupowanej Warszawy dzień powszedni, Warszawa 2010, s. 201.
} s. 29. 
Śródmieście ucierpiało ponownie w wyniku nalotu dywanowego w nocy z 12 na 13 maja 1943 r. Najbardziej zniszczono zabudowę ulicy Marszałkowskiej i placu Zbawiciela, a także kamienice przy Emilii Plater. Ponownie ofiarą bombardowań stała się dzielnica północna $\mathrm{z}$ terenem getta ${ }^{7}$.

Ostatnie radzieckie bombardowanie miało miejsce we wrześniu 1944 r. Celem nalotu były głównie umocnione obiekty niemieckie w Śródmieściu, m.in. budynki Sejmu, koszary przy ulicy Rakowieckiej, aleja Szucha z siedzibą Gestapo, jak również gmach Muzeum Narodowego czy okolice Ogrodu Saskiego.

Kwestia strat poniesionych wśród polskiej ludności cywilnej, jak i zniszczeń w dzielnicach mieszkalnych Warszawy, powstałych w wyniku nalotów radzieckich była jednym z tematów pomijanych i cenzurowanych w oficjalnym nurcie historiografii Polski Ludowej. Trudność w rzetelnym udokumentowaniu skutków bombardowań przez lotnictwo ZSRR okupowanej przez Niemców Warszawy wynika również z faktu wydania 30 czerwca 1941 r. przez gubernatora dystryktu warszawskiego Ludwiga Fischera zarządzenia, w którym zabroniono fotografowania zabudowy przemysłowej i mieszkalnej, uszkodzonej podczas nalotów. Fischer obawiał się wykorzystania tych ujęć w akcji propagandowej przeciwko III Rzeszy8.

Likwidacja getta doprowadziła do unicestwienia wyjątkowego fragmentu przedwojennej Warszawy, tzw. dzielnica północna (nazywana również dzielnicą żydowską) znacznie różniła się swoim charakterem od ścisłego centrum Śródmieścia. Była to dzielnica kontrastów między bogactwem a biedą, co miało również odzwierciedlenie $\mathrm{w}$ architekturze - przeludnione kamienice $\mathrm{z}$ oficynami i ciemnymi podwórkami po jednej stronie, po drugiej - wspaniała zabudowa kamieniczna placu Muranowskiego i ulicy Muranowskiej. Jak wiemy, 19 kwietnia 1943 r. wybuchło powstanie w getcie, które zakończyło się spaleniem i zrównaniem z ziemią przez hitlerowców tego terenu. Z dzielnicy północnej w kształcie z 1939 r. zachowało się zaledwie kilka obiektów architektonicznych, które w dużym stopniu uległy nadpaleniu.

Okres powstania warszawskiego to kolejny etap intensywnego niszczenia tkanki miejskiej. Jedną z metod walki Niemców z oddziałami powstańczymi było palenie domów mieszkalnych i innych obiektów. Generalny gubernator H. Frank w pamiętniku pod datą 5 sierpnia 1944 r. zapisat:

\footnotetext{
7 L. LandaU, Kronika lat wojny i okupacji, t. 2, Warszawa 1962, s. 410-411.

8 W. BARTOSZEWSKI, op. cit., s. 259.
} 
Warszawa stoi prawie cała w płomieniach. Palenie domów jest też najpewniejszym środkiem pozbawiania powstańców kryjówek (...). Po tym powstaniu i jego zgnieceniu Warszawa ulegnie zasłużonemu zupełnemu zniszczeniu9 9

Po kapitulacji powstania nastąpiło wysiedlenie ludności lewobrzeżnej Warszawy. Dowództwo niemieckie powołało specjalne oddziały niszczycielskie (Vernichtungskommando), których celem było doszczętne zniszczenie miasta. Oddziały te przez kolejne trzy miesiące burzyły domy, zieleń miejską, wysadzały infrastrukturę podziemną. Przebieg tej systematycznej akcji dobrze obrazuje relacja Antoniego Czarkowskiego, ukrywającego się w ruinach spalonej kamienicy przy ulicy Marszałkowskiej:

W ciszy, jaka w tym okresie zapanowała, często miały miejsce silne detonacje. (...) Takie postępowanie pozwoliło nam ustalić, że jest to systematyczne, bez popłochu i zbytniego pośpiechu, wysadzanie domów ${ }^{10}$.

Efekt, jaki przyniosła realizacja rozkazu unicestwienia miasta, wzbudzał przerażenie również wśród niemieckiego wojska - fotograf Joe J. Heydecker, wówczas żołnierz Wehrmachtu, 20 listopada 1944 r. zanotował:

Miasto, przez które idę z kolegą (...), jest upiorne. Faktycznie trudno się trzymać myśli, że jesteśmy w prawdziwym milionowym mieście, które całe, naprawdę całe, leży w gruzach, że te resztki murów dookoła nie są surrealistyczną filmową scenografią ${ }^{11}$.

Po wyzwoleniu lewobrzeżnej Warszawy, 17 stycznia 1945 r., rozpoczęło się rozminowywanie ruin miasta przez polskie oddziały saperskie. Miejski Sztab Rozminowania Warszawy pod dowództwem płk. Piotra Puzerewskiego otrzymał wyraźne wytyczne odgórne: po pierwsze, rozminowanie miasta i budowę mostów, po drugie, udrożnienie arterii miasta jako ważnego węzła komunikacyjnego dla posiłków i zaopatrzenia dla armii idącej dalej na zachód. W trakcie akcji saperskiej dochodziło do niszczenia zachowanych fragmentów kamienic i budowli zabytkowych. Było to spowodowane zarówno ogromną ilością nowoczesnych materiałów minerskich pozostawionych przez Niemców, jak i presją

9 Cit.per: A. Ciborowski, op. cit., s. 48.

${ }^{10}$ Cit. per: Martwe miasto, wybór T. Borkowski, [w:] Zagtada miasta. Świadectwa ludzi Powstania, Warszawa 2020, s. 181.

11 Cit.per: ibidem, s. 188-189. 
czasu, by z Warszawy jak najprędzej uczynić przepustowy węzeł komunikacyjny. Bardzo często dochodziło do wypadków podczas akcji rozminowywania i przypadkowego wyburzania zabudowań. Jako przykład takiego niekontrolowanego wyburzenia można przywołać nieudaną akcję rozbrajania powstańczej barykady na ulicy Puławskiej ${ }^{12}$. Prace przy rozminowywaniu trwały do 17 marca 1945 r., kiedy nastąpiło oficjalne przekazanie terenu władzom miejskim.

Straty, jakie poniosło miasto w okresie II wojny światowej, najwyraźniej obrazuje porównanie kubatury zabudowy z 1939 r. z oszacowaną podczas pierwszej po wojnie akcji inwentaryzacji, przeprowadzanej przez BOS do końca 1945 r. $-73 \mathrm{mln} . \mathrm{m}^{3}$ miasta (ze $103 \mathrm{mln} . \mathrm{m}^{3}$ ) uległo zagładzie ${ }^{13}$. Dzielnicą, która najbardziej ucierpiała, było Śródmieście. W sprawozdaniu przedstawionym na VII Sesji Krajowej Rady Narodowej w maju 1945 r. kierownik BOS Roman Piotrowski referował: „Najwięcej ucierpiało śródmieście, gdzie procentowa liczba domów całkowicie zniszczonych wynosi $60,08 \%$, a ilość ocalałych zaledwie 15,33\%"14. Można postawić pytania: dlaczego przedstawione dane nie sumują się do 100\%? Dlaczego wiele budynków o wartości historycznej nie było branych pod uwagę jako kwalifikujące się do rekonstrukcji? Dlaczego liczne kamienice nie były rekonstruowane zgodnie z ich przedwojennym wyglądem? Bez wątpienia decydowały o tym względy ideologiczne oraz fakt, iż „stały one na drodze" wizji nowej Warszawy, realizowanej przez planistów z BOS. W organie prasowym BOS, tygodniku „Skarpa Warszawska”, pod datą 21 października 1945 r. czytamy:

Czy odbudowywać wszystko bez wyboru i wyjątków? i formy przeżyte lub obumierające? i to, co spróchniałe od wewnątrz, szpetne i koślawe? i to, co związane z krzywdą, na przemocy wyrosłe? Nie! Jest więc odbudowa budowaniem od nowa. W stosunku do tego stanie się nieraz przebudową, nieraz nawet potwierdzeniem wyroku zniszczenia. (...) Warszawa musi być uzdrowiona urbanistycznie ${ }^{15}$.

12 J. Górski, Warszawa w latach 1944-1949. Odbudowa, Warszawa 1988, s. 69-70.

13 A. Ciвorowski, op. cit., s. 56. Nieco inne przeliczenie strat zawierają współczesne obliczenia, w których ubytek kubatury szacowany jest na $70 \mathrm{mln} . \mathrm{m}^{3}$. Zespół ds. ustalenia wartości strat, jakie Warszawa poniosła w wyniku II wojny światowej, Raport o stratach wojennych Warszawy, Warszawa 2004, s. 60.

14 Referat R. Piotrowskiego na VII Sesji KRN, [w:] Odbudowa Warszawy w latach 1944-1949. Wybór dokumentów i materiatów, red. J. GóRSKI, t. 2, Warszawa 1977, s. 364-365.

15 Od Redakcji, „Skarpa Warszawska” 1945, nr 1, s. 1. 


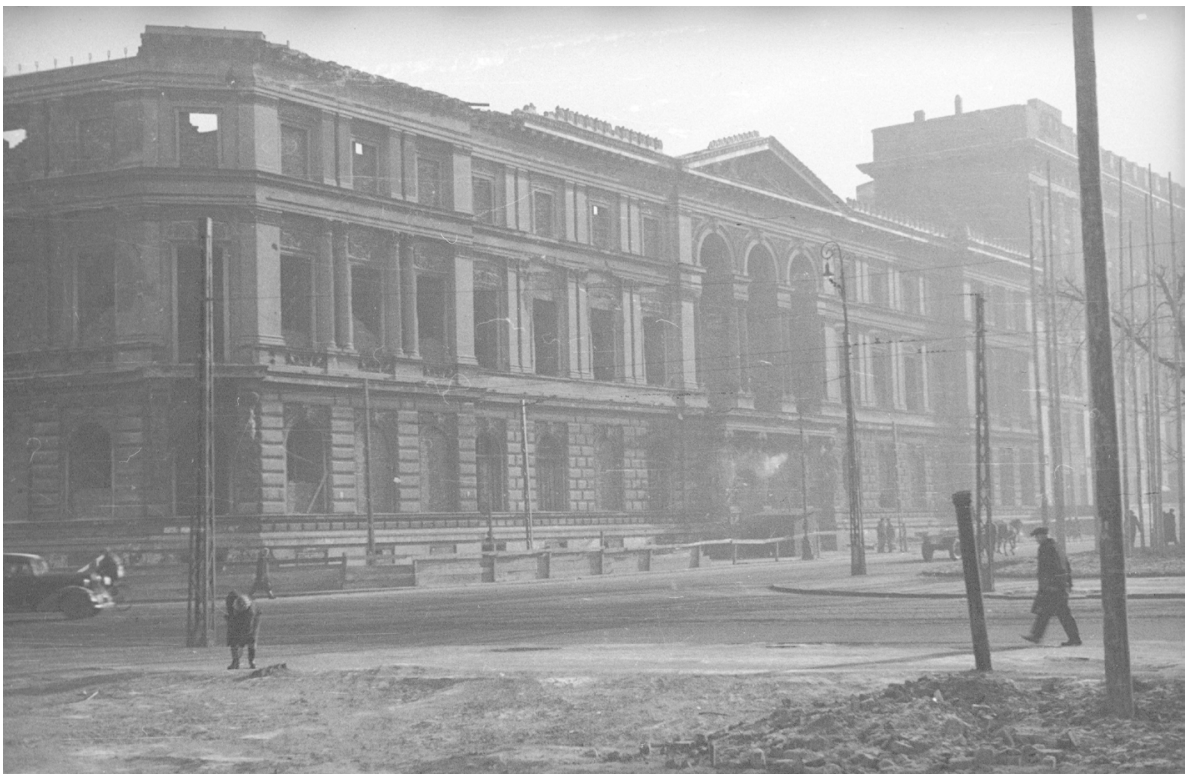

Ryc. 2. Koszary Wołyńskie (Artylerii Koronnej) przy ul. Zamenhofa 19 na rogu z ul. Gęsią w 1961 r. (źródło: Narodowe Archiwum Cyfrowe, Archiwum fotograficzne Lecha Zielaskowskiego, sygn. $3 / 53 / 0 / 8 / 641)$

Aby zilustrować proces dalszego burzenia przedwojennej zabudowy Warszawy, trwający do końca lat sześćdziesiątych XX w., warto przywołać historię trzech śródmiejskich obiektów: koszar Wołyńskich, pałacu Kronenberga i kamienicy Goldstandów (Ryc. 2-4).

$\mathrm{Na}$ terenie getta wojnę przetrwały zabytkowe koszary Artylerii Koronnej. Budynek miał spaloną część fasady frontowej, natomiast tylne części kompleksu nadawały się do zagospodarowania. Plany nowego przeznaczenia budynku kilkakrotnie się zmieniały, jeszcze w 1946 r. zamierzano umieścić w nim władze dzielnicy Muranów. Innym pomysłem na zagospodarowanie kompleksu była jego przebudowa na budynek mieszkalny dla pracowników Ministerstwa Kultury. Żaden z tych planów nie uzyskał akceptacji BOS. Budynek jeszcze w $1960 \mathrm{r}$. był w bardzo dobrym stanie, rozebrano go jednak w 1965 r. ${ }^{16}$

Podobny los spotkał pałac Leopolda Stanisława Kronenberga. Konstrukcja budynku zachowała się do końca wojny w stanie pozwalającym na szybką

16 A. Bojarski, Warszawa utracona. Pierwsze lata odbudowy, Warszawa 2020, s. 43-44, 232. 


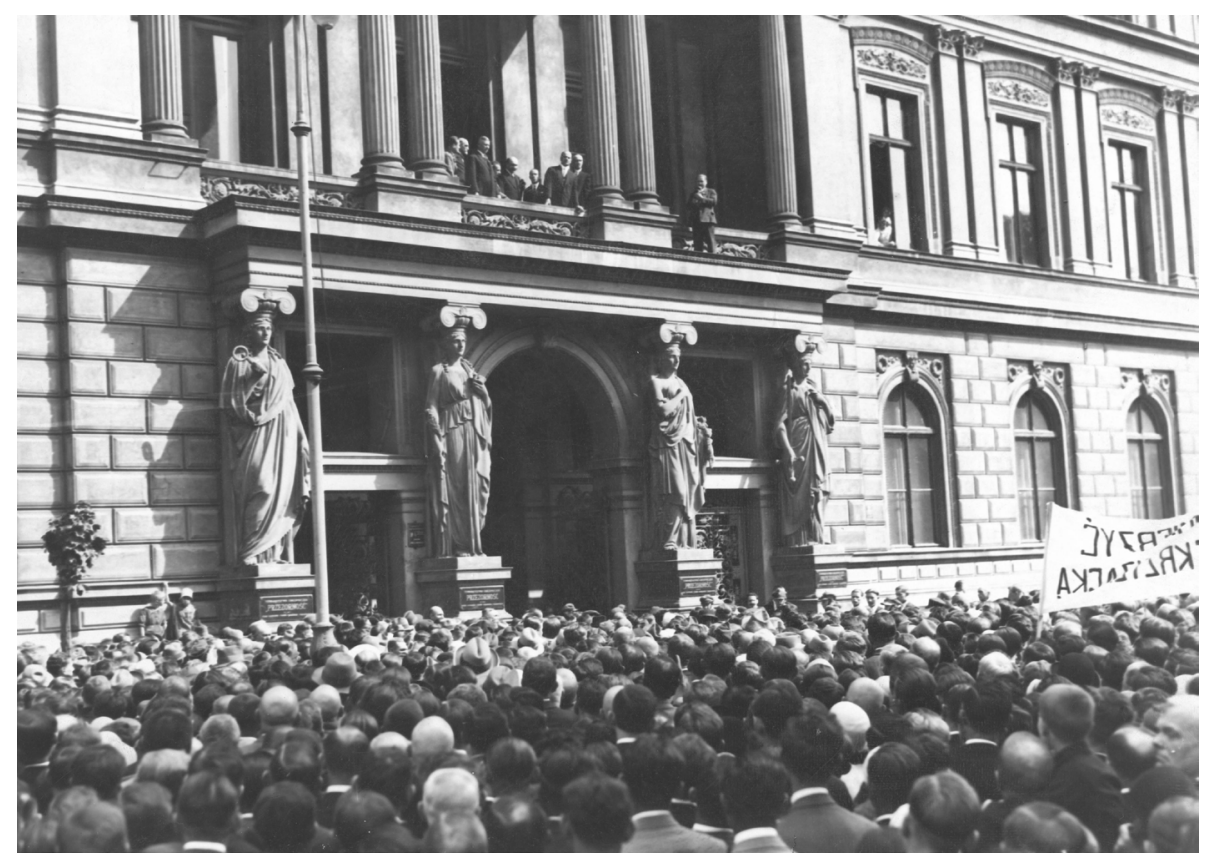

Ryc. 3. Uczestnicy manifestacji przed Pałacem Leopolda Stanisława Kronenberga u zbiegu ul. Królewskiej i Placu Małachowskiego w 1930 r.

(źródło: Narodowe Archiwum Cyfrowe, Koncern llustrowany Kurier Codzienny - Archiwum Ilustracji, sygn. 3/1/0/6/2853)

rekonstrukcję. Ta jednak nie nastąpiła i w 1959 r. gmach został skreślony z rejestru zabytków, a pozostałości jego murów wyburzono.

W retoryce BOS posługiwano się określeniem „kamienicy dochodowej”. Budynki mieszkalne wpisujące się w tę kategorię skazywano na rozbiórkę bądź przebudowę. Takim obiektem była kamienica Goldstandów. Dom z niewielkimi uszkodzeniami ocalał z wojennej pożogi, nadawał się do odbudowy w pierwotnym kształcie ${ }^{17}$. Jednakże BOS zarządziło jego przebudowę. Budynek radykalnie obniżono do czterech kondygnacji (pierwotnie było ich dziewięć), fasadę okuto z ornamentyki, kolumn, balkonów. Z największego domu mieszkalnego w Warszawie dwudziestolecia międzywojennego kamienica ta stała się pozbawionym charakteru elementem zabudowy otaczającej plac Dąbrowskiego.

Istotny jest również rozdźwięk między głoszoną przez funkcjonariuszy partyjnych i BOS oceną skali zniszczeń zabudowy śródmiejskiej a relacjami ówczesnej prasy i samych warszawiaków. Już w pierwszych dniach po wyzwoleniu

${ }^{17}$ Ibidem, s. 266-267. 


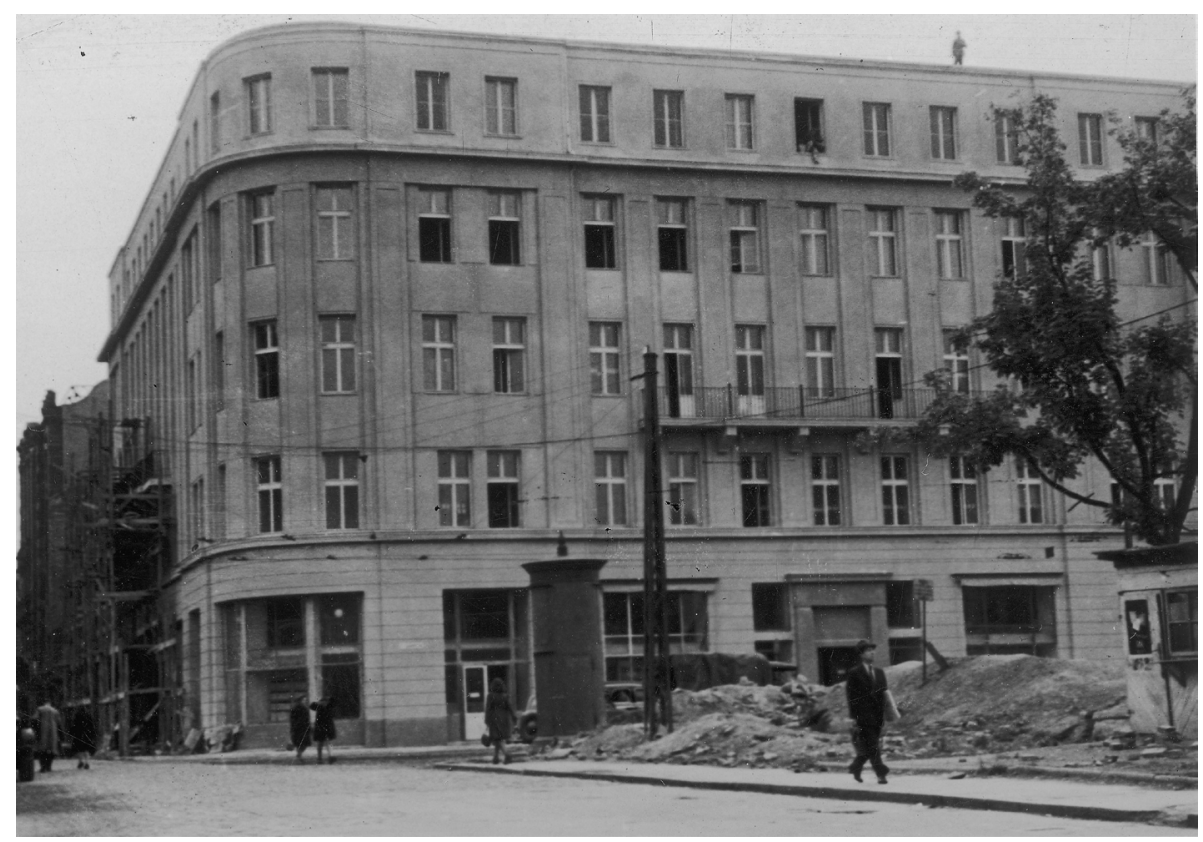

Ryc. 4. Odbudowana kamienica Goldstandów przy Placu Dąbrowskiego 8 w 1947 r. (źródło: Narodowe Archiwum Cyfrowe, Socjalistyczna Agencja Prasowa, sygn. 3/3/0/47/1138)

winą za ruinę miasta została obarczona wyłącznie strona niemiecka. Ta interpretacja była stale podtrzymywana, a Bolesław Bierut, jeszcze cztery lata po zakończeniu wojny, przypominał w referacie wygłoszonym na Zebraniu I Konferencji Warszawskiej PZPR:

Dla dyszących nienawiścią i zemstą zbrodniarzy hitlerowskich, którzy na krótko przed własną śmiertelną klęską burzyli planowo miasto, paląc i niszcząc przez szereg miesięcy dom za domem, aby nie pozostało z Warszawy kamienia na kamieniu - ostateczna zagłada miasta zdawała się być faktem nieodwracalnym ${ }^{18}$.

Skala zniszczeń - obiektywnie ogromna - była jeszcze bardziej wyolbrzymiana $\mathrm{w}$ oficjalnej propagandzie. Pierwszy powojenny prezydent miasta, Marian Spychalski, w wywiadzie dla „Życia Warszawy” wypowiadał się następująco: „Nie tylko zostały zniszczone wszystkie domy i obiekty przedstawiające

18 B. Bierut, Sześcioletni plan odbudowy Warszawy, referat wygłoszony na Konferencji Warszawskiej PZPR w dniu 3 lipca 1949 r., Warszawa 1950, s. 39. 
jakąkolwiek wartość utylitarną, ale zniszczono również obiekty wielkiej kultury i sztuki"19. Jednakże korespondenci tego samego dziennika w dniu 20 stycznia 1945 r. donosili: „Odcinki Wilczej, Hożej, Wspólnej między Kruczą a Marszałkowska są względnie całe”20. W tym samym piśmie odnajdujemy relację z 2 lutego 1945 r. na temat zachowanych ponad dwudziestu kamienic wzdłuż Marszałkowskiej ${ }^{21}$. Jak podkreśla Artur Bojarski:

Gdyby była wola zachowania tego, co w roku 1945 ocalało lub nadawało się do odbudowy, przynajmniej jakąś część przedwojennej Warszawy moglibyśmy odzyskać, tamtej Warszawy, niepowtarzalnej w skali całego kraju i jego historii. Żadne inne duże miasto polskie nie może w najmniejszym stopniu zastąpić Warszawy skalą wielkomiejskiej zabudowy XIX i XX wieku, polskością jej architektury czy liczbą i znaczeniem zgromadzonych tam zabytków ${ }^{22}$.

Aby zrozumieć proces niszczenia pozostałości po świetności Śródmieścia lat trzydziestych XX w., świadczącego o majętności i władzy klasy mieszczańskiej, trzeba odnieść się do podwalin ideologicznych budowania Warszawy „na nowo” przez władze komunistyczne oraz wspierających je architektów i urbanistów.

\section{Założenia ideologiczne architektury i planowania przestrzennego miast}

Zgodnie z zasadami estetyki marksistowskiej architektura stanowi żywą część ogólnej materialnej i duchowej kultury danego narodu ${ }^{23}$. Dzieło architektoniczne jest dostępne każdej jednostce. Fakt ten czyni z architektury bardziej demokratyczną formę sztuki, niż są malarstwo czy rzeźba, z którymi obcowanie było zarezerwowane w historii ludzkości zazwyczaj dla wąskiej grupy odbiorców. Za jej pomocą najpełniej można zatem realizować wychowawczą

19 Po uwolnieniu stolicy. Wywiad zprezydentem m.st. Warszawy ptk. inż. M. Spychalskim, „Życie Warszawy: Informacyjne pismo demokratyczne miasta stoł. Warszawy” 1945, nr 19, s. 1.

${ }^{20} W$ drugim dniu po oswobodzeniu. Warszawa $\dot{z} y j e$, „Życie Warszawy: Informacyjne pismo demokratyczne miasta stoł. Warszawy” 1945, nr 19, s. 1.

21 Jak wygląda nasza ulica? Wędrówka po Marszatkowskiej, „Życie Warszawy: Informacyjne pismo demokratyczne miasta stoł. Warszawy" 1945, nr 33, s. 4.

22 A. BOJARski, op. cit., s. 27.

23 S. Morawski, Szkice z podstawowych zagadnień estetyki marksistowskiej, Kraków 1951, s. 109. 
funkcję sztuki. Podczas zebrania architektów, które odbyło się 5 listopada 1944 r., Wincenty Rzymowski podkreślił:

W chwili obecnej przed architekturą polską otwiera się wielka misja; musi ona zająć się nie tylko budową, ale i odbudową kraju. (...) Architektura to nie tylko budownictwo mieszkań czy monumentalne. Architektura to także budowanie psychiki zbiorowej. (...) Ulice wielkiego miasta prowadzą naród albo w kierunku postępu, albo w kierunku zacofania, albo do wielkości, albo do skarlenia, zależnie od tego, jak i przez kogo są budowane. Architektura (...) może budować na kościach ludzkich albo na fundamentach sprawiedliwości społecznej; może budować dla próżniaczej elity i dla wszystkich ludzi pracy ${ }^{24}$.

W Polsce teoretyczne założenia socrealistycznej architektury odwoływały się zarówno do wzorców radzieckich, jak i przedwojennych projektów przebudowy miast $\mathrm{w}$ celu najpełniejszego dostosowania ich zabudowy do potrzeb ludności. Istotnym punktem odniesienia dla założeń odbudowy polskich miast była ogłoszona podczas IV Międzynarodowego Kongresu Architektury Nowoczesnej z 1933 r. Karta Ateńska Le Corbusiera. Krytykowano w niej relację między interesami prywatnymi a publicznymi w miastach. Wskazywano występujący od początku XX w. wzrost interesów prywatnych, które nie były podporządkowane potrzebom zbiorowym, co z kolei powodowało zaburzenie równowagi między naporem sił ekonomicznych a nadzorem administracyjnym nad nimi. W efekcie w miastach postępowała dysproporcja w warunkach życia w dzielnicach robotniczych i burżuazyjnych ${ }^{25}$.

Dezurbanizmowi przeciwstawiono zasadę zwartości miasta, która determinowała strukturę zabudowy przestrzennej. Miasto powinno tworzyć układ stosunkowo zwięzły, a kompozycje architektoniczne - wiązać się ze sobą w całość. W praktyce oznaczało to powrót do założeń osiowych z budownictwem wzdłuż brzegów placów i ulic. Nowe miasta miały posiadać centra o charakterze społeczno-politycznym oraz place i ulice, traktowane jako tereny życia zbiorowego $^{26}$.

Stolica miała stać się modelowym przykładem miasta socjalistycznego, dlatego też nowe władze dążyły do zmiany jej składu społecznego. Służyła temu

${ }^{24}$ Cit.per: J. Sigalin, Warszawa 1944-1980. Z archiwum architekta, t. 1, Warszawa 1986, s. 29.

25 A. Kotarbiński, $O$ ideowości $i$ ideologii $w$ architekturze $i$ urbanistyce, Warszawa 1985 , s. $33-43$.

26 A.K. Olszewski, Dzieje sztuki polskiej 1890-1980, Warszawa 1988, s. 86. 
m.in. polityka migracyjna. Pod pretekstem ciężkich warunków bytowych już w 1945 r. rozpoczęto wysiedlanie starych mieszkańców Warszawy. Na tereny Ziem Odzyskanych była przenoszona inteligencja i wykwalifikowani robotnicy. Do stolicy masowo zaczęto sprowadzać ludność pochodzenia wiejskiego.

Drugą kwestią, która miała znacząco wpłynąć na skład społeczny stolicy, było uregulowanie spraw własności gruntu, tak by uzyskać swobodę w kształtowaniu przestrzennego zagospodarowania terenu ${ }^{27}$. Stąd jednym z pierwszych posunięć władzy w zakresie zagospodarowania stolicy było wydanie przez prezydenta Krajowej Rady Narodowej Dekretu o wtasności i użytkowaniu gruntów na obszarzem.st. Warszawy ${ }^{28}$. Akt ten, popularnie nazywany „dekretem Bieruta”, wszedł w życie 21 listopada 1945 r. Głosił że „,w] celu umożliwienia racjonalnego przeprowadzenia odbudowy stolicy i dalszej jej rozbudowy zgodnie z potrzebami narodu, w szczególności zaś szybkiego dysponowania terenami i właściwego ich wykorzystania" ${ }^{29}$ nastąpi przejęcie na własność gminy wszystkich gruntów w obrębie Warszawy. Dotychczasowy właściciel gruntu mógł w ciągu pół roku od wejścia w życie dekretu ubiegać się o przyznanie mu prawa do jego wieczystej dzierżawy. Od tej zasady obowiązywał jednak wyjątek głoszący, że jeśli użytkowanie danego terenu będzie stać w sprzeczności z planem zabudowy miasta, gmina powinna zaproponować byłemu właścicielowi działkę o porównywalnej wartości w innym miejscu lub wypłacić odszkodowanie ${ }^{30}$.

Miasta zawierają w sobie nie tylko tkankę architektoniczną i urbanistyczną, równie ważny jest ich przekaz symboliczny i onomastyczny. Jest to przekaz

${ }^{27}$ Koncepcja ta była nawiązaniem do klasycznej pracy Silvia Gesella z 1916 r. pt. Naturalny porzadek gospodarczy poprzez wolna ziemię $i$ wolny pieniadz oraz jej zastosowania przez Hansa Bernoulliego w teorii planowania zdrowych miast. Bernoulli po wizycie w Polsce w okresie międzywojennym opublikował artykuł Rozwój urbanistyczny Warszawy, poświęcony analizie zabudowy przestrzennej miasta. Wyróżnił w nim kilka podstawowych problemów urbanistyki Warszawy, wynikających z chaotycznego gospodarowania gruntami: wadliwą budowę sieci ulicznej, zbyt gęstą zabudowę Śródmieścia, niejednorodność zabudowy pod względem jej wysokości i ciągłości, skutkującą dominacją w krajobrazie miasta nagich ścian szczytowych kamienic. M. PopIOŁEK, „Miastu - grunty, mieszkańcowi - dom". Historia powstania dekretu Bieruta na tle europejskiej myśli urbanistycznej, [w:] Spór o odbudowę Warszawy. Od gruzów po reprywatyzacje, red. T. Fudala, Warszawa 2016, s. 42, 50-52.

${ }^{28}$ Dekret o wtasności i użytkowaniu gruntów na obszarze m.st. Warszawy, Dz.U. z 1945 r. Nr 50, poz. 279 , s. 434-435.

29 Ibidem, s. 434.

${ }^{30} \mathrm{~W}$ praktyce kwestie odszkodowań nie były realizowane - miasto przejmowało swobodnie większość nieruchomości. 
mówiący zarówno o historii danej społeczności miejskiej, jak i pamięci historycznej szerszej wspólnoty - wspólnoty narodowej. Jak słusznie zauważył Jakub Sadowski:

Skoro stolica jest modelem świata, wyposażonym w same superlatywy, obdarzonym atrybutem zwierzchności administracyjnej i „depozytem władzy” zajmującej centralne miejsce w homogenicznej mitologii wspólnoty, to stosunek do centrum administracyjnego kraju będzie stosunkiem do całego wspólnotowego świata. Oznacza to, że nie można szanować państwa, nie szanując jego stolicy ${ }^{31}$.

W propagandowym przekazie odbudowa Warszawy jako centrum kraju i wspólnoty narodowej urasta do rangi symbolu.

Nowe rozplanowanie Śródmieścia było szczególnie ważne. Architektura z przełomu XIX i XX w. w ścisłym centrum miasta była traktowana jako symbol burżuazyjnej metropolii, której ślady chciano wymazać. W założeniach komunistów Śródmieście, z jednej strony, miało spełniać funkcję dzielnicy rządowej, z drugiej - świadczyć o równości społecznej panującej w stolicy. Osiągnięciu tego drugiego celu służyłoby budownictwo mieszkaniowe, w którego ramach miały powstać osiedla robotnicze. W celu zmiany oblicza społecznego dzielnicy uruchomiono ogromną machinę propagandową, w którą włączono m.in. twórców kultury. Słowa z przemówienia B. Bieruta: „Pod robotnicze osiedla mieszkaniowe zostaną oddane tereny, które dawniej były dostępne jedynie dla zamożnej ludności Warszawy, mieszkania robotnicze wejdą do śródmieścia wzdłuż trasy W-Z i ulicy Marszałkowskiej"32 - były przekładane dosłownie na język poezji (w 1950 r. ukazał się wiersz Adama Ważyka Lud wejdzie do śródmieścia $\left.{ }^{33}\right)$. Pierwszy etap przebudowy Śródmieścia miał się zakończyć skoncentrowaniem budownictwa mieszkalnego dla robotników, usytuowanego wzdłuż pięciu głównych tras: Krakowskie Przedmieście - Belweder, trasa W-Z, Marszałkowska, Aleje Jerozolimskie i Oś Saska ${ }^{34}$ (Ryc. 5).

31 J. SAdowski, Między Patacem Radi Patacem Kultury. Studium kultury totalitarnej, Kraków 2009, s. 119.

32 Ibidem, s. 181.

33 A. WAŻYK, Wiersze 1940-1953, Warszawa 1953, s. 53.

34 Ustawa o planie sześcioletnim, „Architektura” 1950, nr 7/8, s. 196. 


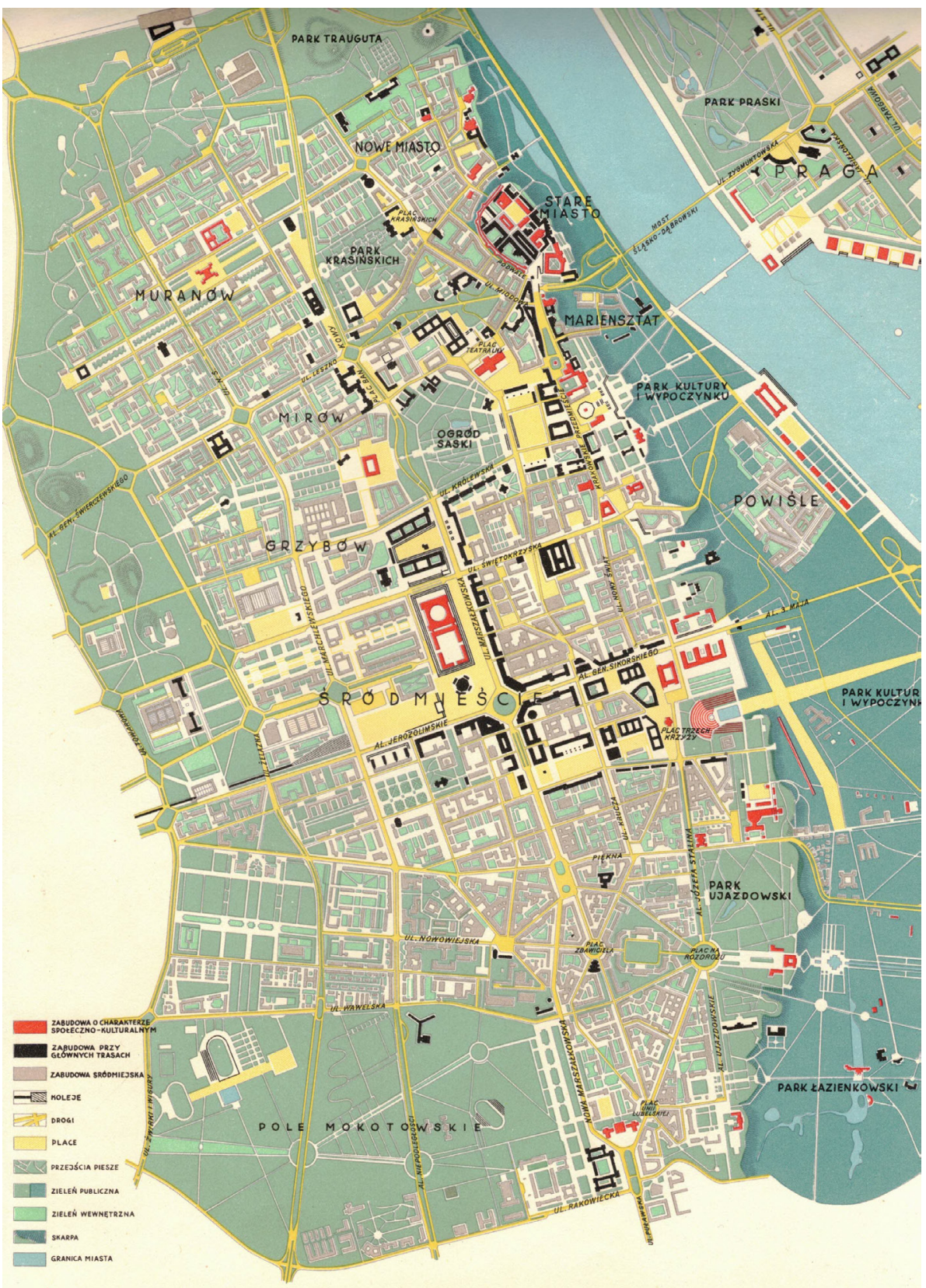

Ryc. 5. Główne założenia Śródmieścia w Planie 6-letnim

(źródło: B. BIERUT, Sześcioletni plan odbudowy Warszawy, Warszawa 1950, s. 273) 


\section{Realizacja założeń ideologicznych w działalności Biura Odbudowy Stolicy}

Główne założenia BOS i jego skład personalny zaczęły kształtować się jeszcze przed powołaniem do życia samej instytucji. Pierwsze plany przebudowy stolicy nawiązywały do koncepcji architektów okresu międzywojennego z Pracowni Architektoniczno-Urbanistycznej Warszawskiej Spółdzielni Mieszkaniowej, Społecznego Przedsiębiorstwa Budowlanego czy Polskiego Towarzystwa Reformy Mieszkaniowej. W obrębie tych instytucji powstawały plany przebudowy miasta jako harmonijnej wspólnoty ożywionej ideą egalitaryzmu ${ }^{35}$. Doświadczenia wyniesione z okresu II RP wspominał Marian Spychalski: „Specjaliści od spraw zabudowy miejskiej pragnęli ze względów społecznych uzdrowić żywiołowy, szkodliwy dla mieszkańców miasta proces urbanistyczny, początkowo całkowicie podporządkowany prawu największego zysku" ${ }^{36}$. W odwołaniu do przedwojennych idei architekci tworzyli - już w okresie okupacji - projekty uzdrowienia miasta. Istotne propozycje dla późniejszych planów BOS przedstawił Stanisław Dziewulski, który pisał:

Przedmiotem (...) jest nie tylko odbudowa, lecz również gruntowna przebudowa Warszawy, zmierzająca do naprawienia błędów jej rozwoju w ciągu ostatniego stulecia, powrotu do zdrowej tradycji urbanistycznej oraz zaspokojenia w pełni współczesnych potrzeb społecznych, artystycznych i technicznych w życiu wielkiego miasta ${ }^{37}$.

Kształtowanie zaplecza personalnego BOS rozpoczęło się 22 stycznia 1945 r. w Lublinie wraz z utworzeniem Grupy Operacyjnej „Warszawa”. W jej skład weszli Józef Sigalin, Lech Niemojewski, Bohdan Lachert, Eleonora Sekrecka, Julian Sadłowski, Hanna Sigalin. W sprawozdaniu z pierwszej wizyty w Warszawie L. Niemojewski poruszył kilka ważnych kwestii dotyczących Śródmieścia, a wśród postulatów przeznaczonych do realizacji wymienił wytyczenie szlaków alei N-S, Nowego Światu bis, alei Na Skarpie, ulicy Zielnej i poszerzonej ulicy

${ }_{35}$ M. SoŁtys, Zanim powstato Biuro Odbudowy Stolicy - odbudowa domów przy ulicy Nowy Świat po zniszczeniach 1939 roku, [w:] Archiwum Biura Odbudowy Stolicy, red. J. LEw IŃsKA, Warszawa 2011, s. 15.

${ }^{36}$ M. SPYCHALSKI, Warszawa architekta. Wspomnienia pierwszego powojennego prezydenta stolicy, Warszawa 2015, s. 44-47.

${ }^{37}$ E. Perlińska-Kobierzy Ńska, Warszawa, Miasto do przebudowy, [w:] Spór..., s. 61. 
Marszałkowskiej, odbudowę fasad kamienic na Nowym Świecie i Krakowskim Przedmieściu ${ }^{38}$. M. Spychalski powołał 22 stycznia 1945 r. Biuro Organizacji i Odbudowy Warszawy (BOOW) z Janem Zachwatowiczem na czele, które 14 lutego 1945 r. zostało przekształcone w Biuro Odbudowy Stolicy, a jego kierownictwo objął Roman Piotrowski, zastępcami zostali zaś Witold Plapis i Józef Sigalin ${ }^{39}$.Zaplecze personalne instytucji bardzo szybko się rozwijało i już w lipcu 1945 r. liczyło półtora tysiąca osób.

Decydującą rolę w kształtowaniu planów przebudowy Warszawy odgrywało ścisłe kierownictwo, wśród którego większość działaczy była powiązana z PPR, nieliczni mieli zapatrywania socjalistyczne, jak Kazimierz Marczewski, czy byli niezależni jak profesorowie Jan Zachwatowicz i Piotr Biegański.

BOS nie było jedyną organizacją odpowiedzialnąza odbudowę stolicy. W proces ten włączyły się też Naczelna Rada Odbudowy Warszawy, Obywatelska Liga Odbudowy Warszawy oraz Komitet Odbudowy przy premierze. Często dochodziło do sporów kompetencyjnych czy wydawania sprzecznych decyzji. Zdanie BOS jednak zdecydowanie dominowało. Wynikać to mogło z faktu, że Biuro cieszyło się przychylnością prezydenta Bieruta, który objął wyraźnym, choć nieoficjalnym, patronatem proces odbudowy miasta. Władze BOS były powiązane bezpośrednio z Moskwą, co dawało im przewagę w wielu kwestiach nawet nad polskimi instytucjami państwowymi.

Pierwszy okres działalności BOS skupiał się głównie na prowadzeniu akcji inwentaryzacyjnej i odgruzowywania stolicy. W końcu kwietnia 1947 r. J. Sigalin objął kierownictwo Pracowni Głównej BOS, odpowiedzialnej za wytyczenie nowych planów urbanistycznych dla stolicy. Przyjęto dwie podstawowe zasady rekonstrukcji architektury przedwojennej: po pierwsze, odbudowa powinna objąć tylko te obiekty, których umiejscowienie nie stwarza przeszkód w rozwoju miasta, po drugie, nie należy dopuszczać do odbudowy tych obiektów, których usytuowanie jest niezgodne z nowym planem ${ }^{40}$.

Można stwierdzić, że do 1948 r. BOS cieszyło się dużą swobodą w podejmowaniu decyzji, a uzależnianie środowiska architektów od decyzji władz partyjnych rozpoczęło się w 1948 r. po ustanowieniu Państwowego Biura

\footnotetext{
38 Ibidem, s. 75.

39 G. PiĄTEK, op. cit., s. 85.

40 P. Majewski, Ideologia i konserwacja. Architektura zabytkowa w Polsce w czasach socrealizmu, Warszawa 2009, s. 21.
} 
Projektowego. Kolejnym krokiem do ograniczenia samodzielności BOS było utworzenie 30 grudnia 1949 r. - na wzór radziecki - Komitetu ds. Urbanistyki i Architektury przy premierze. Zmiany te były początkiem procesu zmierzającego do likwidacji BOS, która nastąpiła na mocy rozporządzenia Rady Ministrów z 6 września 1950 r. Kompetencje BOS zostały przekazane Radzie Narodowej m.st. Warszawy i jej organom, główną rolę w zagospodarowywaniu stolicy zaczęło odgrywać Biuro Urbanistyczne Warszawy ${ }^{41}$.

W działalności planistycznej BOS można wyróżnić dwa okresy: pierwszy to powstanie planów odbudowy stolicy w latach 1945-1946 i próby ich implementacji, drugi to okres po przełomowym roku 1949 trwający do likwidacji instytucji. Odnosząc te dwa okresy do przebudowy Śródmieścia, należy stwierdzić, że pierwszy z nich zaowocował wieloma nowatorskimi inicjatywami urbanistycznymi, z których większość jednak nie została zrealizowana. W drugim okresie powstały ściśle zideologizowane plany, ograniczające się głównie do robotniczego budownictwa mieszkalnego.

Śródmieście miało stać się ośrodkiem społecznym, administracyjnym, gospodarczym, mieszkalnym i dzielnicą wyższych uczelni. Po 1945 r. powstało dużo projektów konkretnych budowli czy kompleksów, które nie doczekały się realizacji, wśród nich można wymienić kompleks Centrali „Społem” i Powszechnego Zakładu Ubezpieczeń Wzajemnych czy zabudowę Dworca Centralnego ${ }^{42}$. Rozpisywano liczne konkursy architektoniczne, rekordowy w tym zakresie był 1947 r., kiedy rozstrzygnięto aż dziesięć konkursów na budowę monumentalnych gmachów. W 1948 r. rozstrzygnięto konkurs na projekt budynku Powszechnego Domu Towarowego, w którym zwyciężyła praca Zbigniewa Ihnatowicza i Jerzego Romańskiego ${ }^{43}$.

Ważnym wymiarem idei Śródmieścia jako centrum decyzji politycznych było zaprojektowanie tzw. „Osi Ministerialnej”, na której tylko część budynków została zrealizowana, jak nowy gmach Ministerstwa Komunikacji przy ulicy Chałubińskiego oraz Ministerstwo Przemysłu i Handlu, natomiast część nigdy nie powstała, m.in. gmach Warszawskiej Dyrekcji Kolei Państwowych ${ }^{44}$.

${ }^{41}$ A. Skalimowski, Skazani na wielkość? Biuro Odbudowy Stolicy 1945-1951, [w:] Spór..., s. $105-106$.

${ }^{42}$ J. GórsKi, op. cit., s. 340-341.

${ }^{43}$ Konkurs nr 165 na rozwiazanie architektoniczne budynku PDT $w$ Warszawie, „Architektura” 1948, nr 5, s. 110.

${ }^{44}$ J. GórsKi, op. cit., s. 343-345. 
Niektóre plany BOS były nierealistyczne i brak ich realizacji oszczędził przed zniszczeniem wiele unikatowych fragmentów miasta. Przykładem może być plan wyburzenia do końca 1945 r. ogromnego kwartału miasta między ulicami Marszałkowską - Alejami Jerozolimskimi - Towarową i Chodną w celu realizacji nowego planu zabudowy Śródmieścia ${ }^{45}$ (Ryc. 6 i 7).

W wyglądzie ulicy Marszałkowskiej - głównej arterii Śródmieścia - trudno jest się doszukać elementów ogromnego przedsięwzięcia BOS, jakim była koncepcja „rynku Marszałkowskiego”. Z pierwotnej koncepcji został zrealizowany jedynie gmach PKO, projektu Bohdana Lacherta. Do szuflady powędrowały wyniki rozstrzygniętego w 1949 r. konkursu na hotel Orbis, szkice Domu Chłopa i Domu Związków Zawodowych ${ }^{46}$.

Zapowiedź zmian ideologicznych w urbanistyce odnajdujemy w zapisie obrad Stowarzyszenia Architektów Polskich (SARP) z kwietnia 1949 r. W referacie Władysława Czernego znalazła się krytyka dotychczasowej realizacji wizji BOS: „Nie znaleziono właściwej funkcji i położenia dzielnicy zabytkowej, w związku z tym w Śródmieściu napotykamy spór między zabytkami a nowym życiem" ${ }^{\text {”7 }}$. W dniach 20-21 czerwca 1949 r. odbyła się krajowa partyjna narada architektów, podczas której nastąpiła dalsza krytyka działań BOS. Referat wprowadzający wygłosił Edmund Goldzamt, który podkreślił, że architekturę kształtuje ustrój społeczny. Potępił również wpływ koncepcji burżuazyjnego Zachodu na polską architekturę i niedostateczne wykorzystanie doświadczeń radzieckich. Dotychczasowe plany powstające w BOS skrytykował ostro Stefan Tworkowski: „Główne wady: oparcie się w zasadzie o podstawy naukowe i perfekcjonizm - nieekonomiczność i pozaczasowość doktryny planowania przestrzennego (...), typowy formalizm, wyrosły na gruncie technokratyzmu i utopii społecznych i urbanistycznych - obok konserwatyzm”\$8. Równie krytycznie wobec wczesnego dorobku BOS wypowiadały się władze miejskie, potępiono m.in. założenie zupełnego rozgraniczenia dzielnic przemysłowych od dzielnic mieszkalnych, usunięcie niemal całkowicie mieszkalnictwa

\footnotetext{
45 A. BojARski, op. cit., s. 188.

46 G. PiąTEK, op. cit., s. 368-369.

47 Cit.per: J. Górski, op. cit., s. 323-324.

48 Cit.per: ibidem, s. 325.
} 


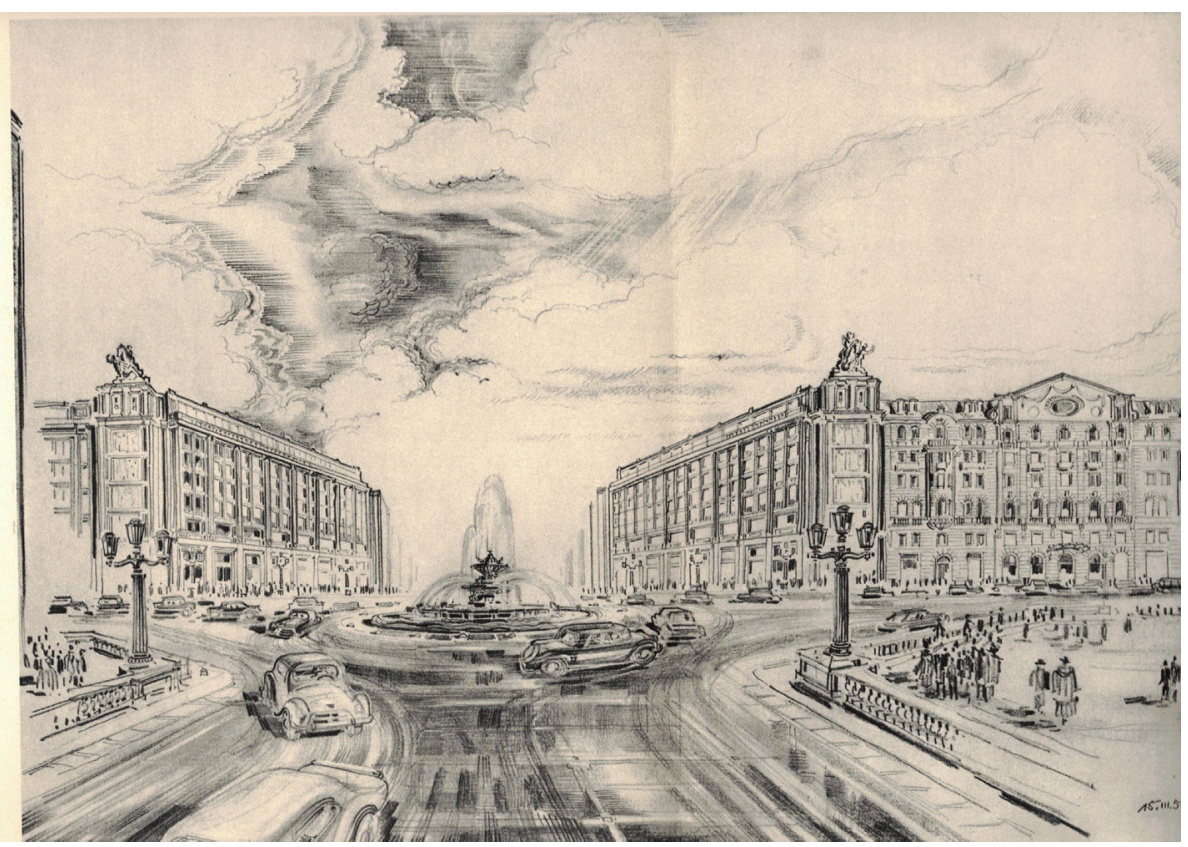

Ryc. 6. Szkic przedstawiający ul. Marszałkowską u zbiegu z Alejami Jerozolimskimi. Zakładany widok ulicy w 1955 r.

(źródło: B. BIERUt, Sześcioletni plan odbudowy Warszawy, Warszawa 1950)

ze Śródmieścia, traktowanego niemal wyłącznie jako centrum dyspozycji administracyjnej ${ }^{49}$.

Przełomowy dla dalszej przebudowy Śródmieścia stał się plan opracowany w czerwcu 1949 r. przez Wydział Urbanistyki BOS. W jego opisie znalazły się sformułowania, że specyficzny wyraz nadadzą Śródmieściu wielkie place zebrań i manifestacji publicznych, natomiast sklepy i lokale rozrywkowe odegrają znacznie skromniejszą rolę. Było to nawiązanie do wypowiedzi Bieruta, który postulował, by teren w centrum stolicy stał się areną wielkich masowych zebrań w dniach uroczystych i ważnych dla całego społeczeństwa ${ }^{50}$.

Założenia planu sześcioletniego były wdrażane już po rozwiązaniu BOS. Hasło Bieruta o wejściu ludu do Śródmieścia zostało częściowo zrealizowane

49 Opracowanie Zarzadu Miejskiego o zniszczeniu Warszawy, jej odbudowie w latach 19441949 oraz perspektywach rozwoju miasta w okresie planu 6-letniego, [w:] Odbudowa..., t. 1, s. 364-365.

50 B. BIERUT, op. cit., s. 265. 


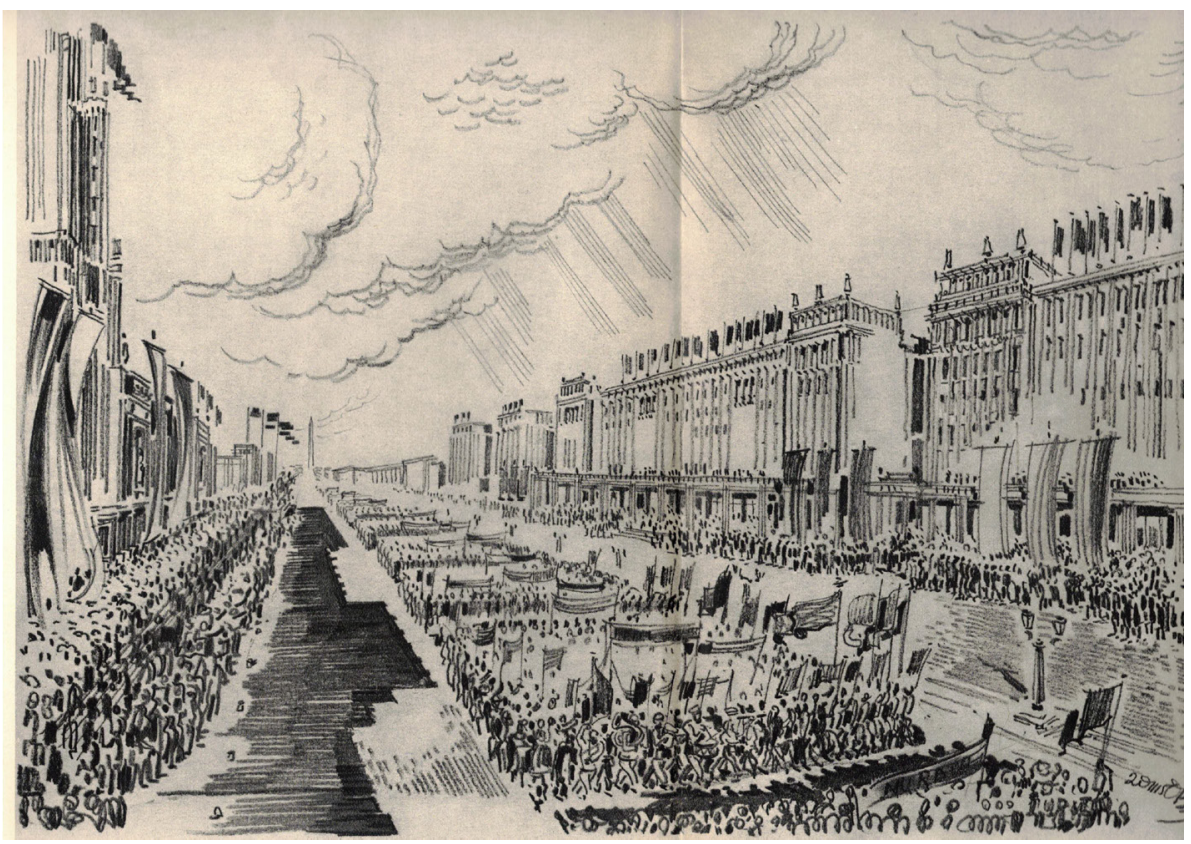

Ryc. 7. Szkic przedstawiający pochód na ulicy Marszałkowskiej.

Zakładany widok ulicy w $1955 \mathrm{r}$.

(źródło: B. BierUt, Sześcioletni plan odbudowy Warszawy, Warszawa 1950, strona nienumerowana)

poprzez budowę Marszałkowskiej Dzielnicy Mieszkaniowej (MDM), za którą odpowiadała w 1951 r. pracownia Stanisława Jankowskiego, Jana Knothego, Józefa Sigalina i Zygmunta Stępińskiego. Projekt ten miał stanowić przejście od rekonstrukcji i odbudowy do budownictwa ściśle uwarunkowanego zagadnieniami politycznymi i społecznymi ${ }^{51}$.

Zmiany przyniesione przez okres odwilży oraz trudności gospodarcze uniemożliwiające pełną realizację planu sześcioletniego spowodowały odejście od restrykcyjnego kierowania się ideologicznymi wytycznymi w architekturze. Wizja przebudowy Śródmieścia, proponowana przez architektów BOS,

51 S. Jankowski, J. Knothe, J. Sigalin, Z. Stępiński, Marszatkowska Dzielnica Mieszkaniowa, „Architektura” 1951, nr 7, s. 233-225. 
nie została zrealizowana. Jej kosztem było natomiast bezpowrotne usunięcie z mapy stolicy unikatowych obiektów historycznych. Kolejne pokolenia odziedziczyły dzielnicę bez wyraźnego charakteru, w której zabudowie trudno jest odnaleźć ideały, jakimi planiści kierowali się tuż po wojnie.

\section{BIBLIOGRAFIA}

\section{Źródła drukowane}

Bierut B., Sześcioletni plan odbudowy Warszawy, referat wygłoszony na Konferencji Warszawskiej PZPR w dniu 3 lipca 1949 r., Warszawa 1950.

Dekret o wtasności i użytkowaniu gruntów na obszarze m.st. Warszawy, Dz.U. z 1945 r. Nr 50, poz. 279.

Odbudowa Warszawy w latach 1944-1949. Wybór dokumentów i materiatów, t. 1-2, red. J. Górski, Warszawa 1977.

\section{Prasa}

„Architektura” 1948, 1950, 1951.

„Skarpa Warszawska” 1945.

„Życie Warszawy: Informacyjne pismo demokratyczne miasta stoł. Warszawy” 1945.

\section{Wspomnienia}

Sigalin J., Warszawa 1944-1980. Z archiwum architekta, t. 1, Warszawa 1986.

Spychalski M., Warszawa architekta. Wspomnienia pierwszego powojennego prezydenta stolicy, Warszawa 2015.

\section{Inne}

Ważyk A., Wiersze 1940-1953, Warszawa 1953. 


\section{Opracowania}

Bartoszewski W., 1859 dni Warszawy, Kraków 2008.

Bojarski A., Warszawa utracona. Pierwsze lata odbudowy, Warszawa 2020.

Ciborowski A., Warszawa. O zniszczeniu i odbudowie miasta, Warszawa 1964.

Drozdowski M.M., Zahorski A., Historia Warszawy, Warszawa 2004.

Dunin-Wąsowicz K., Warszawa w latach 1939-1945, Warszawa 1984.

Górski J., Warszawa w latach 1944-1949. Odbudowa, Warszawa 1988.

Kotarbiński A., O ideowości i ideologii w architekturze i urbanistyce, Warszawa 1985.

Landau L., Kronika lat wojny i okupacji, t. 2, Warszawa 1962.

Majewski P., Ideologia i konserwacja. Architektura zabytkowa w Polsce w czasach socrealizmu, Warszawa 2009.

Martwe miasto, wybór T. Borkowski, [w:] Zagtada miasta. Świadectwa ludzi Powstania, Warszawa 2020, s. 178-201.

Morawski S., Szkice z podstawowych zagadnień estetyki marksistowskiej, Kraków 1951.

Olszewski A.K., Dzieje sztuki polskiej 1890-1980, Warszawa 1988.

Perlińska-Kobierzyńska E., Warszawa, Miasto do przebudowy, [w:] Spór o odbudowe Warszawy. Od gruzów po reprywatyzację, red. T. Fudala, Warszawa 2016, s. 59-91.

Piątek G., Najlepsze miasto świata. Warszawa w odbudowie 1944-1949, Warszawa 2020.

Popiołek M., „Miastu - grunty, mieszkańcowi - dom”. Historia powstania dekretu Bieruta na tle europejskiej myśli urbanistycznej, [w:] Spór o odbudowe Warszawy. Od gruzów po reprywatyzacje, red. T. Fudala, Warszawa 2016, s. 37-58.

Sadowski J., Między Patacem Radi Patacem Kultury. Studium kultury totalitarnej, Kraków 2009.

Skalimowski A., Skazani na wielkość? Biuro Odbudowy Stolicy 1945-1951, [w:] Spór o odbudowe Warszawy. Od gruzów po reprywatyzację, red. T. Fudala, Warszawa 2016, s. 93-107.

Soltys M., Zanim powstato Biuro Odbudowy Stolicy - odbudowa domów przy ulicy Nowy Świat po zniszczeniach 1939 roku, [w:] Archiwum Biura Odbudowy Stolicy, red. J. Lewińska, Warszawa 2011.

Szarota T., Okupowanej Warszawy dzień powszedni, Warszawa 2010.

Zespót ds. ustalenia wartości strat, jakie Warszawa poniosta w wyniku II wojny światowej, Raport o stratach wojennych Warszawy, Warszawa 2004. 


\section{Urszula Kurcewicz}

\section{THE IDEOLOGICAL ASPECTS OF RECONSTRUCTING WARSAW CITY CENTRE FROM THE RUINS OF WORLD WAR II}

Summary. The purpose of this article is to prove that the reconstruction of Warsaw from the devastation brought by World War II was in actuality the construction of a new capital for a socialist state, following Marxist land development principles. The communist authorities considered rebuilding Warsaw City Centre to be of particular importance. Buildings predating the war were seen as symbols of capitalist social relations, which privileged the urban middle class.

The author begins by discussing the historically inaccurate appearances upheld by the Polish Workers' Party, and later by the Polish United Workers' Party, regarding the extent and causes of the damage sustained by the capital in World War II. The propaganda of the new authorities focused primarily on the destructive activities of the Nazi occupiers, whereas the Soviet bombing and the destruction which ensued during the liberation of Warsaw were either ignored or presented in a dishonest manner.

The second part of the article deals with the ideological foundations of rebuilding the City Centre. The communists believed that the capital city should be a relatively compact system organized in the form of multiple architectural compositions forming a cohesive whole. The center of the city was to be socio-political in nature, and its squares and streets were treated as areas for public life. The division into better and worse districts was to be abolished.

The final part of the article constitutes an attempt to determine the extent of the autonomy granted to the architects and planners of the Warsaw Reconstruction Office, and to what extent their plans and concepts had to follow the guidelines of party functionaries.

Keywords: capital city, ideology, reconstruction, Warsaw City Centre, Warsaw Reconstruction Office, architecture, history of Warsaw, urban planning 